\title{
The International Centre for the Protection of Catholic Interests in Palestine: Cultural Diplomacy and Outreach in the British Mandate Period
}

\author{
Paolo Maggiolini
}

The establishment of the International Centre for the Protection of Catholic Interests in Palestine was one of those events in the history of institutions that begin with great ambitions and under the brightest auspices, but soon show their limitations, eventually erasing their traces and disappearing from memory. Nevertheless, its foundation provides a valuable source of information on the development of the views of local Catholic hierarchies of the condition of Christians in Palestine and the role of ecclesiastical and missionary institutions. In particular, it shows that the Latin Patriarchate did not simply operate within the strict limits of religious and missionary activities, but also concentrated on the field of cultural outreach, locally and internationally. With all the limits of the case, the International Centre can be considered a missing tile in the mosaic of the numerous activities undertaken by the Latin Patriarchate during the Mandate to position and develop the local Catholic community.

Although this initiative mainly emanated from the will of the Latin Patriarch, Luigi Barlassina, and it avoided the involvement of local Arab

\footnotetext{
P. Maggiolini $(\bowtie)$

Catholic University of Milan, Milan, Italy

e-mail: paolomaria.maggiolini@unicatt.it
} 
Catholics, it provides important information on how to conceive and understand the development of the local Catholic condition in the post-1929 Mandate political field. The International Centre's microhistory offers evidence of the attention that the Catholic ecclesiastical hierarchy in Palestine paid to the role of information, communication, perception and representation both at local and international levels. It also shows a nuanced understanding of the importance of the media and public opinion in modern society. Finally, it proves the gradual recognition of the strategic role of presiding over such fields, establishing spaces of exchange and outreach. At the same time, being directly supported by the Holy See, it represents an auxiliary source for understanding how the Catholic Church perceived and interpreted ongoing political developments in the land of Palestine during the 1930s. ${ }^{1}$

In these regards, the following analysis focuses mainly on the first dimension, namely that of the Latin Patriarchate and its commitments to the defence of Catholic interests in Palestine.

Historically, the establishment of the International Centre as a non-profit organisation acting in Europe is particularly interesting because it aimed to develop an integrated scheme of coordination between Palestine and the international community, specifically through the medium of an office in Belgium where the Centre's official headquarter was established. ${ }^{2}$ The International Centre was thus composed of two "legs" and one centralised "mind". Officially it was established in Belgium because it was considered the most opportune country in Europe, as is later analysed. The Belgium "leg" was then mirrored by a Palestinian office in Jerusalem directly under the control and management of the Latin Patriarch, Luigi Barlassina. He was the "mind" behind such an initiative and the one who was presiding over, supervising and, sometimes, concretely writing the material to be disseminated.

Such an organisation would have made it possible to disseminate articles, commentaries and op-eds in different languages (mainly French, but there is evidence of the use of Italian, German, Spanish and Dutch) through existing Catholic media outlets. Moreover, the Belgian office would also have organised thematic conferences to inform and aggregate consensus in favour of the Catholic Church in Palestine.

\footnotetext{
${ }^{1}$ For a detailed analysis of the Holy See's views and understanding on the establishment of the International Centre see Paolo Pieraccini, "La Diocesi Patriarcale Latina di Gerusalemme, La Santa Sede e le Grandi Potenze dal crollo dell'Impero ottomano alla Seconda guerra mondiale (1917-1939)" (PhD diss., Università degli Studi di Firenze Facoltà di Scienze Politiche "Cesare Alfieri", 2008-2009), 551-558; Paolo Zanini, "Il Centro internazionale per la protezione degli interessi cattolici in Palestina," Studi storici 54, no. 2 (2013): 415-417.

${ }^{2}$ Archivi Affari Ecclesiastici Straordinari (AAES), IV Periodo, Turchia, Palestina, 131 P.O., fasc. 115 (1932-1936), "Centro internazionale per la Palestina", N.10814, letter from the Nuncio to Belgium, Clemente Micara, to Secretary of the Sacred Congregation of Extraordinary Ecclesiastical Affairs, Giuseppe Pizzardo, Brussels, 28 April 1932, f. 69.
} 
The paper elaborates on this topic according to three different microhistorical axes, namely Barlassina's biography and character, the communication strategy and the instruments employed by the Patriarchate in Palestine (that can be reconsidered according to the idea of local cultural diplomacy) and, finally, the Centre's activity and main production between 1933$1935 / 37$. Ideally, such a partition tries to deconstruct the project proposed by Barlassina in 1930 according to the key elements guiding the concept of cultural diplomacy, explaining the cultural milieu that contributed to the elaboration of the proposal, how the cultural diplomatic ${ }^{3}$ initiative was to be realised and, finally, for the sake of whom and what the Patriarch felt urgent to develop an International Centre dedicated to Catholicism in Palestine.

First, an analysis of the International Centre for the Protection of Catholic Interests in Palestine cannot avoid taking into consideration Barlassina's distinctive and strong personality and character. The Patriarch was widely criticised during his lifetime by the British authorities, Latin and Oriental Catholic hierarchies, the local faithful, Muslims and Jews. ${ }^{4}$ At the same time, Barlassina never held back from criticising or opposing whomever he considered to be limiting and undermining the status and position of Catholicism in Palestine. This attitude and position strongly influenced the Latin Patriarchate during the interwar period, and it provides evidence of the raison d'être for establishing the International Centre's project.

Secondly, contextualising the origin of the Centre from the perspective of the different communication tools Barlassina employed is useful to fully appreciate the project's role within the framework of the Latin Patriarchate's daily activities. In particular, this chapter briefly reconsiders two of the Patriarchate's cultural "devices" at the time, the Patriarch's pastoral letters and the Patriarchal bulletin Jerusalem: le Moniteur diocésain patriarcat latin de Jérusalem (today Archives diocésaines).

Although generally ignored, Barlassina's pastoral letters ${ }^{5}$ contain important elements to develop a parallel path in the history of the Latin Patriarchate and of the configuration of the Patriarchate in the land of Palestine during the Mandate. Clearly, they are important sources for appreciating his pastoral activity and the Patriarchal religious message. But I propose to look at them as useful sources to illuminate an aspect of the history of this institution and of the idea of how to organise and define the position, the boundaries and spheres of the local Catholic community during the Mandate. Founded in 1933, the year of the official announcement of the International Centre, the bulletin Jerusalem: le Moniteur diocésain patriarcat latin de Jérusalem

\footnotetext{
${ }^{3}$ David Clarke, "Theorising the Role of Cultural Products in Cultural Diplomacy from a Cultural Studies perspective," International Journal of Cultural Policy 22, no. 2 (2016): 147-163.

${ }^{4}$ Pieraccini, La Diocesi Patriarcale, 101; Agnes De Dreuzy, The Vatican and the Emergence of the Modern Middle East (Washington: CUA Press, 2016), 95-99.

${ }^{5}$ Archive Latin Patriarchate of Jerusalem, Lettere pastorali (Pastoral letters).
} 
is another interesting source of information for understanding the ratio of Barlassina's project in the field of outreach. ${ }^{6}$ Although it can be considered a traditional instrument of communication and dissemination, the timing of its creation is indicative of the Patriarch's strategic vision and of his idea of centralising and coordinating the Patriarchate's communications strategy, intertwining different levels and embracing multiple dimensions in order to consolidate its role as spokesperson for Catholicism in the Holy Land, in all aspects of the Catholic community's daily life.

The last axis of study focuses on the raison d'être for the establishment of the Centre and its activity. It reveals the Holy See's and Latin Patriarchate's concrete motivations to develop this initiative. It is by searching in the correspondence from its foundation that one can appreciate this initiative as an enterprise in cultural outreach and non-state diffused cultural diplomacy, at least as it was designed. In this regard, the timing of Barlassina's proposal and the personalities involved in its creation help to elaborate on this. The analysis of the establishment of the Centre offers a view of the different Catholic orientations towards local politics in Palestine because it involved a plurality of institutions at their highest level, from the Latin Patriarch (the promoter) to the Pope (who approved the initiative), the Secretary of State of the Vatican and of the Congregation for Extraordinary Ecclesiastical Affairs (who mediated its creation), the Apostolic Delegate (who was required to express his opinion and offer his vision) and the Apostolic Nuncio to Belgium (who concretely selected the members of the Centre, asking the Belgian authorities for official recognition of the institution). At the same time, this final level provides insights into the life of the International Centre and its functioning, or more precisely its shortcomings and dysfunctionalities. Through this axis, one can better understand what were considered the Catholic interests at stake and how they developed during the implementation of the British Mandate and the configuration of local political balances of power after 1929 riots. At the same time, this axis helps to elucidate how and to what extent cultural outreach was interpreted as a useful complementary activity to that of the pontifical diplomacy and the Latin Patriarchate in the spirit of pursuing and defending the position of the Catholic presence within the Holy Land.

\section{The Latin Patriarch Barlassina: A Tireless Fighter}

At the end of the 1950s, Joseph Hajjar published a volume on the history of the Melkite Patriarch Maximos III Mazloum, describing him as "a tireless fighter". 7 Mazloum dedicated his entire life to developing and expanding the Melkite Patriarchate, inevitably entering into conflict with a number

\footnotetext{
${ }^{6}$ Archive of the Latin Patriarchate of Jerusalem (ALPJ), LB 9 Intérets de Catholiques en Palestine, 1930-1933/1935, Conferenze ecclesiastiche sui privilegi e le riforme necessarie.

${ }^{7}$ Joseph N. Hajjar, Un lutteur infatigable: le patriarche Maximos III Mazloum (Harissa: Imprimerie Saint Paul, 1957).
} 
of authorities and personalities throughout the Ottoman Levant and beyond. The relationship with Propaganda Fide ${ }^{8}$ was frequently uneasy, while his dynamism was regularly viewed with suspicion. Barlassina is quite similar. The Patriarch was one of "the tireless fighters" in Mandate Palestine and in the post-Ottoman Levant. He also had a complex personality, sometimes even controversial, with a rigid and strict vision of the world. In essence, Barlassina was one of those personalities who divide and polarise, so that Pieraccini describes him as the "troublesome Patriarch". He frequently overexposed himself, going beyond hierarchies and roles. ${ }^{10}$ His activism and dynamism frequently turned into adventurism, multiplying the number of his enemies and rivals. ${ }^{11}$ The Patriarch was attacked by Catholics in Palestine ${ }^{12}$ as well as by the Greek Orthodox because he was considered a symbol of the will to "latinise"13 the Christian Orient. He was criticised by Zionists and Muslims, the former seeing him as an opponent of the Zionist enterprise, the latter often depicting his attitude as a foreign intrusion and will to control. At one point he was considered for removal because of criticism from the British authorities, who did not appreciate his activism. He had a very difficult relationship with the Franciscans and the Melkite Church, such that

\footnotetext{
${ }^{8}$ Propaganda Fide was the Congregation charged by the Holy See with supervising all missionary activities abroad and entertaining contacts with the Uniate Churches, namely the Catholic Eastern Churches as they were defined at that time.

${ }^{9}$ Paolo Pieraccini, "Il Patriarcato Latino di Gerusalemme (1918-1940): Ritratto di un patriarca scomodo: Mons. Luigi Barlassina,” Il Politico, nos. 2-4 (1998): 207-256, 591-639.

${ }^{10}$ The Apostolic Delegate, Gustavo Testa, sketched a vivid portrait of the Latin Patriarch Luigi Barlassina describing him as a man of agitated zeal. Archivio Sacra Congregazione per le Chiese Orientali (ASCCO), Latini, Palestina e Transgiordania: Patriarcato di Gerusalemme, 559/41 $(603 / 28)$, "Ricorso contro Mgr. Barlassina", report from the Apostolic Delegate, Gustavo Testa, on the Latin Patriarch, Luigi Barlassina, 4 March 1937.

${ }^{11}$ The Apostolic Delegate, Testa, recalled that Barlassina entertained strained relationships with Greek Catholic clergy, religious congregations in general, the Custody of the Holy Land, Zionism and the Jews, and, finally, the Palestinian Government. Ibidem.

${ }^{12}$ On this the Archive of the Sacred Congregation for the Oriental Churches has preserved a conspicuous documentation. During the 1920s, the Latin Patriarchate of Jerusalem was strongly criticised by part of the local Catholic community. The criticisms expressed by the Melkite Church are well known and documented. They petitioned the Holy See to dissolve the Latin Patriarchate in order to promote the Melkite Church as the true expression of Eastern Catholicism. Such positions were constantly revived until Vatican II. Less known are the criticisms from a component of the Latin Catholics both of Palestine and Transjordan, asking for the full Arabisation of the Latin Patriarchate. Regarding the first issue see: ASCCO, Latini, Palestina e Transgiordania: Patriarcato di Gerusalemme, 335/37, "Relazioni tra il Patriarcato latino ed il clero orientale". Concerning the second issue see: ASCCO, Latini, Palestina, Latini Palestina Aff. Generali e Del. Apostolica, 417/Prop, "Movimento di scenofobismo contro il clero straniero ed il Comitato Cattolico di Betlemme".

${ }^{13}$ Latinisation has represented a long-discussed issue in the relationship between Western and Oriental Catholicism-Christianity. In essence, it refers to the suspicion that Western Catholic missionaries were trying to transform Oriental Christianity according to the liturgy and the cannon of the Western Catholic Church.
} 
the Apostolic Visitor Robison was openly requested to investigate possible remedies and solutions to heal the fragmentation affecting local Catholics in Palestine and Transjordan. ${ }^{14}$ Finally, he was constantly supervised by the Apostolic Delegate, who recognised his integrity and dedication but never refrained from criticising what he considered Barlassina's limited diplomacy and prudence.

Nevertheless, his strong temperament made him an absolute protagonist in the history of Latin Catholicism during the Mandate. He served as Patriarch for 27 years, the duration of the British Mandate. Moreover, although generally ignored by the literature on Mandate Palestine, he was among those few personages with a position of responsibility in negotiating with the British authorities and local leaderships (both Arabs and Jews) for the whole Mandate period, having being nominated General Vicar in 1918, then Apostolic Administrator in 1919 and finally Patriarch in 1920, a position that he held until 1947. Therefore, he can be considered an important figure in the history of the struggle to define the future of this land.

He was totally dedicated to making the Latin Patriarchate a pivotal institution, not simply in the life of local Latin Catholics, but for Catholicism as a whole in the Holy Land and in post-Ottoman Palestine and Transjordan. In fact, he was also well respected and well thought of for his abilities and dedication. His antagonists and critics often became supporters of this complex personality. He opposed nationalist attitudes and was equally suspicious of Western foreign influences and Arab nationalist or Zionist ambitions. Nevertheless, he always mediated for and voiced the interests of the local populace, being considered by some Arab Palestinians an ally in their struggle. ${ }^{15} \mathrm{He}$ was thus expressing a complex form of local patriotism, centred on the role and value of Latin Catholicism in the Holy Land. In this regard, he was both a "troublesome Patriarch" and a "tireless fighter" for the interests of the Catholic community in the Holy Land, equally concerned for the spiritual and material needs of his diocese. ${ }^{16}$ These were the coordinates defining his conception of what Catholic presence in Palestine was and how it should be understood.

The Patriarch perceived the Catholic community as existentially threatened and under siege both by external and internal enemies. ${ }^{17}$ In this regard, the 1929 Palestine riots were revelatory. Barlassina saw in this struggle, mainly

${ }^{14}$ AAES, IV Periodo, Turchia, Palestina, 61 P.O, fasc. 64 (1925-1931), "Proposta per la nomina di un Visitatore o Delegato Apostolico. Nomina di P. Robinson. Sua missione," 2-6.

${ }^{15}$ AAES, IV Periodo, Turchia, Palestina, 108 P.O, fasc. 103 (1929-1933), "Situazione in Palestina. Prot. n. 3457." Report from the Apostolic Delegate, Valerio Valeri, to the Secretary of State, Pietro Gasparri, Cairo (Zamalek), 22 December 1929, f. 5.

${ }^{16}$ APLG, GV-AG 1.7-1, Visite Canoniche Parrocchie, 1874-1957, "Visita pastorale in Galilea e Transgiordania di Mons. Barlassina, Patriarcha Latino," April-May 1923, Miscellanea.

${ }^{17}$ Archivio Sacra Congregazione Propaganda Fide (ASCPF), Acta, Terra Santa, Missioni di Palestina, vol. 291, pon. 14/VI/1920, "Rapporti tra la Custodia Santa e il Patriarcato. Disposizioni e ordini di Propaganda sui vari punti per un miglior andamento di quelle missioni," f. 280 . 
involving Jews and Muslims, the proof of all his concerns. ${ }^{18}$ In one of his first reports of the clashes, Barlassina explained to Rome that after the riots Christians had been increasingly isolated. Although he was praising them for their decision to remain neutral in the clashes, as the Catholic Church had always advised them to do, Barlassina was also pointing out that such behaviour was now harming Christians' position in the Holy Land. In this regard, the Apostolic Delegate Valeri was in perfect agreement. ${ }^{19}$ While he assured Rome that such behaviour was not producing negative effects for Christians dwelling in the rest of the region, Valeri pointed out that something was changing in the way that Muslims were looking at Christians in Palestine. They were now vocally criticised by Muslims, both in Palestine and Transjordan, and increasingly associated with foreign presences such as that of Britain. ${ }^{20}$ In essence, Barlassina saw in the 1929 riots two overlapping, nefarious dynamics. On the one hand, the Zionist movement had grown stronger after the riots, showing its capacity to exploit tragic events for the sake of its political project. According to him, this was possible mainly because of London's negligence. On the other, Muslims and Christians were now divided with the former looking with suspicion on the latter after their neutrality during the riots of 1929. In his view, this growing fragmentation and isolation affected Catholics in particular. ${ }^{21}$ In this period of growing communitarianism, ${ }^{22}$ Barlassina began to reflect on the future of Catholicism in the Holy Land, and that of Palestine more broadly. In a long report of 1929 that the Patriarch dispatched to Rome, Barlassina made initial suggestions about what would become the project for an International Centre, proposed in 1930. The 1929 riots increased Barlassina's conviction that Catholics were doomed to be condemned to the margins of politics in Palestine. He could not accept such a situation. Barlassina was looking at a community increasingly ignored by the British authorities and viewed with suspicion by Muslims and Jews. In this framework, Barlassina brought forward two proposals to Rome. Firstly, he hinted at the possibility of exploiting the disgust aroused by the riots on the international level to mobilise public opinion to put pressure

\footnotetext{
${ }^{18}$ AAES, IV Periodo, Turchia, Palestina, 108 P.O, fasc. 103 (1929-1933), "Relazione del Patriarca latino di Gerusalemme. N. 279/29," report from the Latin Patriarch of Jerusalem, Luigi Barlassina, to the Secretary of State, Pietro Gasparri, Jerusalem, 29 August 1929.

${ }^{19}$ Ibidem, f. 28. AAES, IV Periodo, Turchia, Palestina, 108 P.O, fasc. 103 (1929-1933), "Situazione in Palestina, N. 56," report from the Apostolic Delegate, Valerio Valeri, to the Secretary of State, Pietro Gasparri, 7 October 1929, f. 74.

${ }^{20}$ AAES, IV Periodo, Turchia, Palestina, 108 P.O, fasc. 103 (1929-1933), "N. 279/29”.

${ }^{21}$ AAES, IV Periodo, Turchia, Palestina, 108 P.O, fasc. 103 (1929-1933), "Conflitti Sanguinosi dell'Agosto. N. 312/29," report from the Latin Patriarch of Jerusalem, Luigi Barlassina, to the Secretary of State, Pietro Gasparri, Jerusalem, 10 September 1929, f. 45r.

${ }^{22}$ Noah Haiduc-Dale, Arab Christians in British Mandate Palestine: Communalism and Nationalism, 1917-1948: Communalism and Nationalism, 1917-1948 (Edinburgh: Edinburgh University Press, 2013), 98; Laura Robson, Colonialism and Christianity in Mandate Palestine (Austin: University of Texas Press, 2011), 63.
} 
on London. ${ }^{23}$ Secondly, the internal disorder in Palestine could be used as proof of the failure of the British Mandate so that it would be possible to revive the idea of internationalising Palestine. In essence, the project of an International Centre for the Protection of Catholic Interests in Palestine developed from Barlassina's tireless activism, his top-down vision of how Catholicism should be defended and represented and, finally, his profound frustration and disillusion with local politics in Palestine after 1929.

\section{The Latin Patriarchate's Cultural Policies During the Mandate}

Although unique in the history of the Latin Patriarchate, the International Centre did not develop in a vacuum. It was a consequential, albeit adventurist, development of how Barlassina interpreted his role as Patriarch and of what resources and devices he considered necessary to fulfil his duties and objectives. This project would provide the Patriarch and Patriarchate with an instrument for reaching out to an international audience, independently from ecclesiastical hierarchies, establishing their voices and priorities. As analysed in the following section, in the mind of the Patriarch the International Centre should be a Catholic realisation of what Zionism had already developed. This can easily be considered a disproportionate ambition, as was noted by some commentators at the time, but these were the Patriarch's intentions.

Before analysing the International Centre's microhistory, it is worth here focusing on two spheres of Barlassina's activity that contribute to elucidating the bases on which the project developed and why at the beginning of the 1930s he suddenly proposed such an initiative. These are his pastoral letters and the two Patriarchal bulletins, the Raqīb Sabyun (1921-1940) and the Moniteur diocésain (created in 1933).

Although already an integral part of the community life of Latin Catholics since the revival of Patriarchate in 1847, pastoral letters became a tool that Barlassina widely employed to communicate regularly with the local Catholic community. Accordingly, the Patriarch interpreted the pastoral role of such an instrument in its fullest sense. Barlassina was a prolific writer. During the Patriarchate of Piavi (1889-1905) one can find in the Jerusalem archives nine pastoral letters (nearly one for each year of his service) and the same for his successor Camessei (acknowledging that he served as Patriarch during the Great War), Barlassina left thirty-two documents. One should bear in mind the length of each Patriarch's term of office (Barlassina served for 27 years, from 1920 to 1947 ) and the different political conditions at the time. ${ }^{24}$

\footnotetext{
${ }^{23}$ AAES, IV Periodo, Turchia, Palestina, 108 P.O, fasc. 103 (1929-1933), "Conflitti Sanguinosi dell'Agosto. N. 312/29," report from the Latin Patriarch of Jerusalem, Luigi Barlassina, to the Secretary of State, Pietro Gasparri, Jerusalem, 10 September 1929, f. 45r.

${ }^{24}$ ALPJ, Lettere pastorali (Pastoral letters).
} 
But he was not simply distinctive from previous Patriarchs for the number and frequency of his pastoral letters. Rather it was his approach, style and the many messages conveyed in them that make such documents important for the present analysis. This is a characteristic that the Patriarch evidenced in all fields of activity. In this regard, two brief elucidations help us appreciate Barlassina's stance and rationale. On the one hand, he decided for the first time to publish his pastoral letters not only in the liturgical language of the Church or in those mostly spoken in the Patriarchate and diocese (Latin, Italian, French and Arabic), but also in English, the idiom of the political authorities, with the aim of establishing a clear and honest relationship with them, as he explained in his correspondence. His pastoral letters should not only speak to his flock but were designed to transmit his message to "all" Palestine. On the other, through his pastoral letters Barlassina promoted a precise idea of the Latin community's boundaries and spheres, in particular in the field of morality and education. Local Catholics should live within the firm boundaries of the community and the Church, refraining from involvement in militant politics or utilising services provided by other communities and non-Catholic institutions. ${ }^{25}$

In this framework, the first pastoral letter published in 1920 can be considered a summation of Barlassina's future service in Palestine. In the letter of March 1920, Barlassina presented himself to his community, taking the opportunity to inform the civil authorities, the British, of how he would interpret his role. ${ }^{26}$ There are two main messages condensed in the following sentence from his first pastoral letter: "We shall grant Caesar what belongs to Caesar, and We know, also Caesar will give to God what is God's due, whilst We warn all the faithful to bear in mind: obedite praepositis vestris [obey to your authorities], both religious and civil, because every authority proceeds from God". ${ }^{27}$ Barlassina offered full collaboration with the British authorities. Nevertheless, he also outlined that this was in exchange for their full cooperation. At the same time, he invited his community to obey and respect the authorities, following the Patriarchate's orders. Barlassina would dedicate all his service to voicing these objectives. He committed himself to defending Catholic interests and Church autonomy against any possible limitations by the Palestinian authorities. He was also strenuously devoted to erecting precise community boundaries at cultural and political levels, holding centre stage in all possible issues concerning Catholicism. This can be considered a

\footnotetext{
${ }^{25}$ Regarding this issue see also: Karène Sanchez-Summerer, "Linguistic Diversity and Ideologies among the Catholic Minority in Mandate Palestine. Fear of Confusion or a Powerful Tool?" British Journal of Middle Eastern Studies 43, no. 2 (2016): 191-205.

${ }^{26}$ ALPJ, Lettere pastorali (Pastoral letters), "Aloysius Barlassina. Miseratione Divina et Apostolicae Sedis gratia. Electus Patriarcha Hierolosolymitanus. Ad Clerum et Populum. N. 1," Jerusalem, March 1920, 10.

${ }^{27}$ Ibidem, 11.
} 
useful standpoint for reconsidering the significance and role of the outreach initiatives developed by Barlasinna during the 1930s both at local and international levels.

Almost in synchrony with the foundation of the International Centre, in 1933 Barlassina also promoted the publication of a new monthly bulletin, Jerusalem: le Moniteur diocésain patriarcat latin de Jérusalem. This was devised as an instrument dedicated to collecting and disseminating information considered important for the life of the Latin community, especially in the fields of liturgy and canon law. As with the pastoral letters, the publication of a bulletin does not represent a particular innovation per se. Rather it can be considered the last tile in the mosaic of Latin Patriarchate's communication strategy. The publication of monthly or weekly journals by religious institutions was not unique in Palestine. Since 1921 the Franciscans had been publishing La Terra Santa. In the same year, the Patriarchate promoted its own publication, the Raqīb Sabyunn. ${ }^{28}$ Published only in Arabic, this journal was meant to provide regular updates on socio-political issues concerning the life of the Church in Palestine. Its function was thus eminently local, although copies were occasionally sent to Rome. In this framework, as emerges from the documentation preserved in Jerusalem, the foundation of the Moniteur diocésain served a slightly different need. It not only provided the Patriarchate with a new device within a new field, but it also perfectly combined with the mission that the International Centre would perform at the international level. First, the Moniteur diocésain was designed to act as a bridge between the Patriarch, the faithful and the different religious orders working in Palestine. ${ }^{29}$ Accordingly, while pastoral letters guided the community's moral and theological dimensions and the Raqīb Sabyūn provided Latin worshippers with more "mundane" information, the Moniteur diocésain reinforced coordination between the Patriarchate, the Catholic religious orders and, thus, the whole Latin community, dealing with liturgy and canon law. Moreover, it published excerpts of or information about conferences organised by Catholic institutions in Palestine dealing with related issues. Conferences were of equal importance for the quality and saliency of the issues discussed and for the opportunities they offered for exchange and coordination. For example, in 1934, while the International Centre was trying to establish itself, a number of conferences were organised involving the Patriarchate, Salesians, White Fathers, Carmelites, Franciscans

\footnotetext{
${ }^{28}$ For accessing its issues see Arab Newspaper Archive of Ottoman and Mandatory Palestine at https://web.nli.org.il/sites/nlis/en/Jrayed.

${ }^{29}$ ALPJ, LB 9 Intérets de Catholiques en Palestine, Conferenze ecclesiastiche sui privilegi e le riforme necessarie, 1935, "Report of monthly conferences, 1934", miscellanea, 2. See also within the same box: "322/35, 6 Febbraio 1935", letter from the Secretary of the Sacred Congregation de Propaganda Fide, Cardinal Fomasoni-Biondi, to the Latin Patriarch of Jerusalme, Luigi Barlassina.
} 
and Benedictines. The topics discussed went from the moral condition of Palestinian society and Protestant propaganda to the need to coordinate Catholic initiatives on personal status, schools, taxes and exemptions, namely the most urgent Catholic concerns, according to the Patriarchate's vision. ${ }^{30}$

In this guise, the Moniteur was meant to be a sort of official magazine for the Catholic Church in the Holy Land. It was also envisaged to be read in public. ${ }^{31}$ The Moniteur established an alternative channel of communication to instruct Latin Catholics at the local level and coordinate the activity and life of Catholic religious orders. It was also a tool for providing authentic information on the Patriarchate's activities. In this regard, the bulletin was aimed at creating an autonomous sphere of exchange between the Authority, namely the Church, and all its components. ${ }^{32}$

Therefore, the International Centre for the Protection of Catholic Interests in Palestine can be appreciated as a sort of culmination of Barlassina's activism, raising to the international level his aim of mobilising international Catholic public opinion to advocate in favour of Catholicism in the land of Palestine. As is analysed below, Barlassina designed the International Centre to be an instrument at his full disposal, reinforcing his idea of being the legitimate spokesperson of the Catholic Church in the Holy Land. It was to become a tool for projecting his diplomatic efforts and transmitting his discourse at the international level. Therefore, while neither Barlassina nor the Latin Patriarchate fully developed a precise rationale or a fully organised strategy of cultural diplomacy during these decades, these initiatives attest to the fact that the Patriarch had a clear understanding of the political and diplomatic role of culture, knowledge and information both as defensive resources and as tools for projecting a precise idea of the role of his ecclesiastical institution and of the Catholic community within the Mandate political field. The International Centre was not just an alternative tool for echoing his messages. It was to be an innovation in quality and vision. The Centre would provide Catholics of the Holy Land with a tool in the field of cultural diplomacy as Zionism had already done. At the same time, it would offer a resource to balance what Palestinian Muslim leaderships were trying to achieve at the beginning of the 1930s with initiatives such the Islamic Conference convened in Jerusalem in 1931. As is analysed later, the International Centre should close the ranks of world Catholicism for the sake of Catholics in Palestine and it would remind British authorities, Zionists and Muslims that their interests in the Mandate were the same of those of world Catholicism.

\footnotetext{
${ }^{30}$ ALPJ, LB 9 Intérets de Catholiques en Palestine, Conferenze ecclesiastiche sui privilegi e le riforme necessarie, 1935, "Séances Ecclésiastique, 27-28 Septembre 1934," 1-4.

${ }^{31}$ Ibidem.

${ }^{32}$ Ibidem.
} 


\section{The International Centre for the Protection of Catholic Interests in Palestine and Its Raison D'Étre}

As emerges from the archival documentation, the idea of founding an organisation to represent and defend Catholic interests in the Holy Land was probably already in Barlassina's mind in the 1920s. Although how to realise it had not been clearly expressed and conceived yet, the Patriarch was looking with concern to the Catholic condition within the Mandate political field. Barlassina had always been determined to have a say in all aspects concerning the life of Catholicism in the Holy Land. He placed no limits on his role and interests, conceiving the Patriarchate as an institution called to embrace the whole life of its community. The fall of the Ottoman Empire and the abolition of the French Catholic protectorate (1920-1924) imposed on Catholic hierarchies the duty of re-negotiating the position of Catholicism in the Mandate and its religious and political rights. ${ }^{33}$ These tasks were perceived with great concern, particularly because Catholic hierarchies, and especially Barlassina, often suspected that British authorities favoured the development of both Anglicanism and Zionism to the detriment of Catholicism. In this framework, since the early 1920s Barlassina had shown a firm conviction that the defence of Catholicism could be achieved only by winning the battle for representation and ideas. In 1922, the Patriarch sent a report to Rome in which he directly expressed his concerns about recognition of a "Zionist committee" in the Mandate, lamenting the lack of a similar institution for Catholics. ${ }^{34}$ According to his statements, this kind of institutional representation could have lessened the shortage of material resources and the weakness of local Arab Catholics' political influence, reinforcing Catholicism and providing local hierarchies with a formal channel to effectively negotiate with the British authorities. ${ }^{35}$ Barlassina always looked with concern on the development of Zionism, in both the political and cultural domains. ${ }^{36}$ Therefore, his strenuous battle for ideas began well before the proposal of the International Centre. As stated above, the 1929 riots can be considered the turning point in his mind. The riots polarised the Palestinian constituency, ${ }^{37}$ and Barlassina

\footnotetext{
${ }^{33}$ On this topic see also: Paolo Zanini, "The Holy See, Italian Catholics and Palestine under the British Mandate: Two Turning Points," Journal of Ecclesiastical History 67, no. 4 (2016): 799-818; Paolo Zanini, "The Establishment of the Apostolic Delegation to Palestine, Cyprus, and Transjordan (1929): Cause or Effect of Changes in Vatican Middle East Policy?" Church History 87, no. 3 (2018): 797-822. See also: Roberto Mazza, Jerusalem: From the Ottomans to the British (London: IB Tauris, 2009).

${ }^{34}$ AAES, IV Periodo, Turchia, Palestina, 6 P.O, fasc. 15 (1922-1939), "Prot. 235/22," letter from the Latin Patriarch of Jerusalem, Luigi Barlassina, to the Secretary of State, Pietro Gasparri, 26 March 1922, f. 45.

${ }^{35}$ Ibidem.

${ }^{36}$ On this topic see: Pieraccini, La Diocesi Patriarcale, 189, 193.

${ }^{37}$ In a letter of 1932, the Apostolic Delegate informed the Holy See that a new front of critics had recently opened against Christians in the Holy Land. Confirming the Swiss priest-journalist Mombelli's article in Fidelis regarding growing hostility towards Christianity in Palestine,
} 
understood this dynamic as the sign of the inevitable marginalisation of the Catholic community in a struggle increasingly involving Zionism, Muslims and British authorities.

Proposed by Barlassina to the Vatican Secretary of State in 1930, the International Centre was officially founded in 1933. Its foundation took long negotiations and a dense exchange of missives between the Latin Patriarch, the Nuncio to Belgium, Clemente Micara; the Vatican Secretary of State, Eugenio Pacelli; that of the Congregation for Extraordinary Ecclesiastical Affairs, Giuseppe Pizzardo; and the Apostolic Delegate, Valerio Valeri. ${ }^{38}$ The idea immediately caught the interest of the pontiff, the Vatican Secretary of State and that of the Congregation for Extraordinary Ecclesiastical Affairs, despite their awareness of the challenges and risks of the enterprise. Before approving Barlassina's project, the Vatican focused on analysing and discussing two main issues, namely which should be the hosting country of the Centre and whether its foundation could prejudice the Holy See's activities.

Regarding the possible seat of the Centre, the Vatican fully took on Barlassina's proposal. He had not only proposed the project, but also signalled Belgium or the Netherlands as possible headquarters. The Nuncio to Belgium, Micara, was then charged with establishing which of the two countries was most suitable. After several weeks Micara suggested Brussels as the best place from which to coordinate the activity of this project. ${ }^{39}$ The choice to establish the Centre in Belgium followed a precise rationale. It was a country with a solid presence in the international organisations of the time, and a Catholic country with a potentially broad audience, predominantly Frenchspeaking, a factor considered of vital importance for disseminating articles and content abroad without excessive translation costs. The presence of the Catholic University of Leuven, with its 4000 students, also ensured an initial

he summarised the recent articles published by a new journal, al-Ğami'a al-Islāmiyya, against Barlassina and Hajjar. He considered this new journal proof of Muslim will to develop an autonomous media in competition with the traditional newspaper Filastīn, owned and founded by an Orthodox Christian, Issa al-Issa. AAES, IV Periodo, Turchia, Palestina, 105-106 P.O, fasc. 101, "Situazione in Palestina. Prot. N. 1209," letter from the Apostolic Delegate, Valerio Valeri, to Secretary of State, Eugenio Pacelli, Jerusalem, 21 November 1932, ff. 46-46r.

${ }^{38}$ The delay in establishing the International Centre was due to a number of factors, including an unexpected reshuffling of the Belgian government, the complexity of selecting appropriate members of the committee and, finally, the intricate procedure required by Barlassina who intended to screen his role in the project in order to present it as an original and independent initiative of willing Catholics in Europe. In this regard, the Patriarch imposed on the Belgian president the dispatch of a series of fake letters presenting the initiative to the Patriarch. In turn, he used them to describe the role and scope of the International Centre to British authorities. For a detailed analysis see Pieraccini, La Diocesi Patriarcale, 551-558; Zanini, "Il Centro," 397-405.

${ }^{39}$ AAES, IV Periodo, Turchia, Palestina, 131 P.O., fasc. 115 (1932-1936), "Centro internazionale per la Palestina," N. 10814, letter from the Nuncio to Belgium, Clemente Micara, to Secretary of the Sacred Congregation of Extraordinary Ecclesiastical Affairs, Giuseppe Pizzardo, Brussels, 28 April 1932, f. 69. 
audience and the necessary intellectual resources to give substance to the project of outreach and dissemination. The Nuncio also pointed out that most Belgium journalists were part of the Association des Journalistes catholique. Micara specified that Delforge, director of the journal Vers l'Avenir of Namur, was also president of the Bureau International des Journalistes Catholiques in Paris, while the Catholic journalist Paul de Lantsheere was the president of the journalists' association in Belgium. Moreover, he considered it possible (as in fact happened) to involve Theunis, the Minister of State and a man of prestige with a strong relationship with the nuncio and an equally uncompromising opposition towards Communism, a factor of great importance for the Holy See, as is explained below. Finally, Belgium was a medium-size power without the overexposure of countries such as France or any concrete interests in the Middle East. Regarding Rome, its exclusion was considered self-explanatory, being the territory where the Vatican and the Holy See are located. It was also agreed to exclude Italy to avoid the risk of raising concerns in France. ${ }^{40}$

As is confirmed by the statute of the organisation, most of these concerns were addressed in the first Committee of the Centre. In fact, Micara managed to win the support of first-rank intellectual and political figures: among the ten founding members, four were ministers of the Belgian government. George Theunis was the president, assisted by Henry Carton de Wiart, Prosper Poullet (both ministers of state and former presidents of the Council of Ministers), Firmin van den Bosch, a distinguished jurist who had been a judge at the mixed court of Cairo, and Fernand van den Corput, a member of the Equestrian Order of the Holy Sepulchre.

Regarding the second issue, there were three main problems that had required some discussion. First, the idea of tracing a parallel between Zionism and the International Centre's mission was considered too ambitious, if not disproportionate. Secondly, the convenience of such a project was doubted, given the fact that the Catholic Church was already well equipped to defend Catholic interests in the Holy Land thanks to its well-established diplomatic corps. Finally came debates over who should be involved and what would be the most appropriate vision driving the work of the Centre.

The archives show that an anonymous commentator called into question the opportuneness of this enterprise and its compatibility with the Holy See's diplomatic activity. In fact, given the nature and sensitivity of the issues and topics that the International Centre would deal with, it could never have been a simple organisation or a league made up of willing Catholics such as those which existed against blasphemy or the trafficking of women. ${ }^{41}$ The main

${ }^{40}$ AAES, IV Periodo, Turchia, Palestina, 131 P.O., fasc. 115 (1932-1936), "Progetto Centro internazionale," N. 108/32, f. 57r.

${ }^{41}$ These were the examples proposed by Barlassina to perorate the establishment of the International Centre. AAES, IV Periodo, Turchia, Palestina, 131 P.O., fasc. 115 (1932-1936), “Appunto Anonimo," N. 750/32, f. 63. 
concern was that its activity could overexpose the Holy See at the international level. This was considered a very serious risk for the authority and prestige of the Vatican. In fact, the anonymous commentator pointed out that it would be difficult to consider the International Centre as a totally autonomous project, independent from the Holy See. Any of its initiatives would inevitably involve Rome, directly or not, with the risk of forcing the Holy See to dissociate or comment, therefore taking a public position. Furthermore, the way the Centre was conceived by Barlassina could implicitly create many possible overlaps between its activity and that of the Holy See's diplomacy. ${ }^{42}$ In order to dispel such doubts, Pacelli and Pizzardo contacted the Apostolic Delegate, asking his opinion of Barlassina's project. ${ }^{43}$ While agreeing about the project's potential, he was cautious. ${ }^{44}$ Although he did not fully share the anonymous commentator's concerns, he did not oppose the project in principle but considered it wiser to focus mostly on the Holy Places, considering their status and defence a priority, to the extent of proposing to involve the Franciscans.

Barlassina did not ignore the challenges at stake either. The Patriarch was aware that his objectives would be difficult to achieve but felt that extreme urgency warranted the effort. It is also probable that he had made reference to Zionism without the real intention to emulate its organisation and scope, but to point out the level of ambition and vision that should inspire the Centre. According to him, the situation in Palestine was not simply dangerous for Catholicism. He was concerned that it could become even worse because of scarce or erroneous information at an international level about the Catholic condition and the challenges at stake. There was an information gap and a lack of concrete awareness. As seen before, the Patriarch could not accept that the future of Palestine would increasingly become an issue involving Jews and Muslims with no consciousness of the needs of Catholics and more widely of Christians. In fact, Barlassina understood that Zionism could never be rivalled, but believed that its strategy and modus operandi could be used as a model. ${ }^{45}$

In conclusion, despite doubts and perplexities, the Centre project had aroused the interest of the Pope and of the Secretary of the Sacred Congregation of Extraordinary Ecclesiastical Affairs. Both considered it

${ }^{42}$ AAES, IV Periodo, Turchia, Palestina, 131 P.O., fasc. 115 (1932-1936), "Appunto Anonimo," N. 750/32, f. 63.

${ }^{43}$ AAES, IV Periodo, Turchia, Palestina, 131 P.O., fasc. 115 (1932-1936), "Progetto Centro internazionale per la Palestina," handwritten notes, 10 February 1932, f. 59.

${ }^{44}$ AAES, IV Periodo, Turchia, Palestina, 131 P.O., fasc. 115 (1932-1936), "Progetto Centro internazionale per la Palestina," "Proposta del Patriarca latino di Gerusalemme. Rapporto di Mons. Valeri (1932)," letter from the Apostolic Delegate, Valerio Valeri, to the Secretary of State, Eugenio Pacelli, 6 March 1932, ff. 61-62.

${ }^{45}$ AAES, IV Periodo, Turchia, Palestina, 131 P.O., fasc. 115 (1932-1936), "Progetto Centro internazionale per la Palestina," N. 108/32, letter from the Latin Patriarch of Jerusalem, Luigi Barlassina, to the Cardinal Secretary of State, Eugenio Pacelli, 2 Febraury 1932, f. 57. 
interesting in terms of outreach and dissemination, potentially beneficial because it was aimed at directly targeting and involving Catholic audiences outside Palestine. ${ }^{46}$ The involvement of Micara helped to dispel many doubts and made the initiative more concrete and feasible. In fact, in 1933 the Patriarch was finally able to inform the High Commissioner, Arthur Wauchope, that his project was fulfilled. After years of thought and constant communication, Barlassina wrote to Wauchope that the long-desired aspiration of 350 million world Catholics to have a stable representation in Palestine had been achieved. ${ }^{47}$ In his mind, the International Centre would now act as the manifestation of the interests and concerns of world Catholicism in Palestine and as the voice of Palestinian Catholicism at the international level. Almost immediately, the Patriarch proceeded with the foundation of the Jerusalem branch. As with the Belgian office, the Jerusalem Committee membership represented the Patriarch's idea of creating an institution expressing the official view of the Catholic Church in Palestine. He only involved religious personalities and superiors of religious orders, excluding local Arab Catholics. In particular, the Jerusalem office saw the contribution of Adolphe Perrin (of the Latin Patriarchate), Antonio Gassi (Custos in the Holy Land), Carrière (Dominican and Prior of St. Etienne, who left the Centre shortly after its establishment), Maistre (Superior of St Pierre de Ratisbonne), Sonnen (Lazarist) and, finally, the priest-journalist Mombelli. ${ }^{48}$

Having analysed how the International Centre was established, it is necessary to focus on what would be its mission and code of conduct. As explicitly stated in its name, the goal of the International Centre was to defend Catholic interests in the Holy Land. ${ }^{49}$ Although the nature of such interests was considered self-evident by the Patriarch (he had not been prolific in detailing them within his numerous missives to Rome), it is important to elucidate what Barlassina had in mind and how the Holy See understood his proposal. In the letter in which he first proposed the project, Barlassina explicitly described them as concerning all issues, laws, procedures and affairs pertaining, directly or not, to the life of the Catholic institutions in the Mandate and the personal status of Catholics dwelling in this territory. These

${ }^{46}$ AAES, IV Periodo, Turchia, Palestina, 131 P.O., fasc. 115 (1932-1936), "Centro internazionale per la Palestina," letter from the Nuncio to Belgium, Clemente Micara, Bruxelles, 2 April 1932, f. 66.

${ }^{47}$ AAES, IV Periodo, Turchia, Palestina, 131 P.O., fasc. 115 (1932-1936), "Centro internazionale per la Palestina," "A. S.E. l'Alto Commissario per la Palestina," letter to the Higher Commissioner, Arthur Wauchope, from the Latin Patriarch of Jerusalem, Luigi Barlassina, Jerusalem, 19 October 1933, F. 105.

${ }^{48}$ ALPJ, LB 9 Intérets de Catholiques en Palestine, 1930-1933/1935, Conferenze ecclesiastiche sui privilegi e le riforme necessarie, "Communication to the Higher Commissioner," Jerusalem, 19 October 1933.

${ }^{49}$ AAES, IV Periodo, Turchia, Palestina, 131 P.O., fasc. 115 (1932-1936), "Progetto Centro internazionale per la Palestina," N. 108/32, letter from the Latin Patriarch of Jerusalem, Luigi Barlassina, to the Cardinal Secretary of State, Eugenio Pacelli, 2 Febraury 1932, F. 57. 
were substantially the rights and interests that at the time of the Ottomans were guaranteed by the French protectorate over Catholics. In early 19291930, Barlassina pointed out that, despite the formal commitments expressed in the Mandate, the British authorities were introducing innovations and postponing final regulations on vital issues for the life of Catholicism, especially regarding the fields of education, taxes and exemptions and marriage. This was occurring without a clear awareness by world Catholicism and international Catholic public opinion. Moreover, the 1929 riots risked clouding the concrete condition of Catholicism in Palestine. Therefore, it would be necessary to establish an alternative mechanism to exert diplomatic pressure on London, without putting the Holy See in a difficult position, and to coordinate the defence of such interests. As evidence of this, after the official registration of the International Centre in the Moniteur Belgique and the exchange of a series of missives to show that it was entirely created by the will of Belgian Catholics without external influences, the Patriarch observed that in the gazette the name of the Centre referred to "religious rights". Barlassina lamented such an inaccuracy, reminding the president of the Centre that he should commit to the defence of all aspects of Catholic life in the Holy Land. The strict reference to the religion was considered a harmful limitation for an institution called upon to defend concrete rights such as those pertaining to schools, charities and personal status. ${ }^{50}$ Legal, political, material and religious dimensions should not be separated. These were all part of Catholic interests in the Holy Land.

From this standpoint, it seems that in the early 1930s the Latin Patriarch was not really interested in containing or confronting Zionism, an issue considered of far more concern by the Secretary of the Congregation for Extraordinary Ecclesiastical Affairs, Luigi Pizzardo, and the new Apostolic Delegate, Torquato Dini. In particular, containing Zionism was understood as an integral part of the wider attempt to confront the development of Communism. ${ }^{51}$ This issue had been highlighted when Micara suggested to the Holy See the name of Theunis as a possible president of the Centre. In 1933, the new Apostolic Delegate, Torquato Dini, reported to the Holy See that the economic development of Zionism and its evident proximity with Communism was the most serious challenge in Palestine. ${ }^{52}$ This alarmed Pizzardo, who wanted to know more. Accordingly, Pizzardo asked Micara

${ }^{50}$ Archivio Segreto Vaticano (ASV), Archivio della Nunziatura in Belgio (ANB), n. 194, N. $562 / 33$, letter from the Latin Patriarch of Jerusalem, Luigi Barlassina, to the President of the International Centre, George Theunis, Jerusalem, 24 October 1933.

${ }^{51}$ In this regard, Pizzardo explicitly instructed the Nuncio Micara. AAES, IV Periodo, Turchia, Palestina, 131 P.O., fasc. 115 (1932-1936), "Ordine di S.E Mgr. Pizzardo," 9 November 1933. See also: Zanini, "Il Centro," 414; Pieraccini, La Diocesi Patriarcale, 556-563.

${ }^{52}$ ASV, ANB, n. 194, "N. 3726/33", from Secretary of the Sacred Congregation of Extraordinary Ecclesiastical Affairs, Giuseppe Pizzardo, to the Nuncio to Belgium, Clemente Micara, Rome, 31 December 1933. 
what the Centre was doing to confront such a challenge. The Nuncio was obliged to reply that the Brussels' office was obliged by the Patriarch to disseminate only contents previously approved by Jerusalem. The Centre was not autonomously doing anything on this subject. It is indicative that the article dispatched by Barlassina in 1933 concentrated on narrating the history of the protection of the Catholic Church's rights from the Ottoman Empire to the British Mandate, totally ignoring Zionism and its development. ${ }^{53}$ During the following years, the Patriarch did not change his viewpoint. Although he made increasing reference to Zionism, its concrete developments and cultural influence in Palestine, Barlassina's standpoint remained structurally connected to what he perceived as a challenge because of the lack of sufficient protection of Catholic rights and interests.

It thus seems clear that for Barlassina, the Centre was not specifically against something or someone but should focus on outreach and dissemination, giving a voice to Catholicism in the Holy Land. As is stated in a pro-memoria preserved in the archive, as "the Jews had founded an Agency, officially recognised and seated in London, for defending their interests and fulfilling their broad projects", Catholics had founded the International Centre to articulate Catholic interests in the Holy Land. ${ }^{54}$ Accordingly, the Centre would concentrate its efforts and resources on issues concerning the daily life of Catholic and ecclesiastical institutions in the Holy Land, without a specific "antagonist". ${ }^{55}$ It would aid Catholics in the Holy Land, avoiding the Holy See's continuous involvement in petitioning for their daily rights so that it could concentrate on the Holy Places, a topic explicitly excluded from the Centre's activities. ${ }^{56}$ These were considered a priority that Barlassina continuously reasserted. The International Centre was specifically designed to appear to the general public as an independent actor detached from the direct control of the Holy See and the Patriarchate. It was also devised to present itself as an authentic and spontaneous initiative of Catholics in Belgium so that the Latin Patriarchate would be left free to act behind it, without being overexposed to the British authorities. ${ }^{57}$ The Belgian headquarters were, in fact, viewed as a sort of necessary functional façade. The Patriarch clearly saw the

\footnotetext{
${ }^{53}$ Pieraccini, La Diocesi Patriarcale, 557-558; ASV, ANB, "Les Institutions Catholiques en Palestine," miscellanea.

${ }^{54}$ ASV, ANB, n. 194, "Pro-Memoria". The same document is preserved at ALPJ, box: LB 9 Intérets de Catholiques en Palestine, Conferenze ecclesiastiche sui privilegi e le riforme necessarie, 1935, "Pro-Memoria".

${ }^{55}$ AAES, IV Periodo, Turchia, Palestina, 131 P.O., fasc. 115 (1932-1936), "Progetto Centro internazionale per la Palestina," N. 108/32, letter from the Latin Patriarch of Jerusalem, Luigi Barlassina, to the Cardinal Secretary of State, Eugenio Pacelli, 2 Febraury 1932, f. 57r.

${ }^{56}$ Ibidem.

${ }^{57}$ ASV, ANB, n. 194, N. 562/33, letter from the Latin Patriarch of Jerusalem, Luigi Barlassina, to the President of the International Centre, George Theunis, Jerusalem, 24 October 1933. See also: Archive Latin Patriarchate of Jerusalem, LB 9 Intérets de Catholiques en Palestine, 1930-1933/1935, "Pro-Memoria," October 1933, F. 25, 2.
} 
Centre as a non-equal partner in the project. Rather, it was to be a transmitter of contents and views that would circulate only after being expressly approved and confirmed by him and his selected entourage. ${ }^{58}$ The Centre would be involved in any issues concerning Catholicism or its traditional rights, but it should also refrain from taking positions and disseminating content autonomously. Only Jerusalem could verify and express the extent of the issues at stake, guiding the Centre's communication strategy. ${ }^{59}$ This was proposed by Barlassina and fully endorsed by the Holy See. ${ }^{60}$ This would also be one of the reasons for the failure of the project once the Belgian office began to prepare excerpts of the long articles dispatched from Jerusalem to make them disseminated more easily. ${ }^{61}$ Such an act of autonomy, combined with protracted delays in publishing articles coming from Jerusalem, irritated Barlassina who progressively lost interest in his creation. ${ }^{62}$

Finally, the International Centre was designed to follow a precise code of conduct. ${ }^{63}$ It was clearly agreed upon to avoid fundraising, an activity already implemented by other institutions. ${ }^{64}$ As seen above, it should avoid direct confrontations with local political actors, especially the British Mandate authorities. ${ }^{65}$ It would also abstain from dealing with economic and financial issues in Palestine. At the same time, all its initiatives should be public and explicit to remind the British authorities and the Jews about its existence. ${ }^{66}$ Accordingly, although the Patriarch never described it as such, he seems to have wished to develop a sort of local Catholic Church soft power through the establishment of the Centre. ${ }^{67}$

The International Centre would be considered an instrument through which Western Catholics could express their concern and solidarity for Catholics in Palestine. It would thus attract support on their behalf, demanding the respect of non-Catholic nations. ${ }^{68}$ From this standpoint, the

${ }^{58}$ ASV, ANB, n. 194, "Riservata," N. 10813.

${ }^{59}$ ASV, ANB, n. 194, "Pro-Memoria".

${ }^{60}$ Ibidem.

${ }^{61}$ ASV, ANB, n. 194, "Lettera n. 187/34," letter from the Latin Patriarch, Luigi Barlassina, to the Nuncio to Belgium, Clemente Micara, Jerusalem, 5 Febraury 1934.

${ }^{62}$ AAES, IV Periodo, Turchia, Palestina, 131 P.O., fasc. 115 (1932-1936), "Progetto Centro internazionale," "Foglio confidenziale con cui la Segreteria informa Barlassina di aver già preso iniziative presso il Comitato e il Nunzio per preoccuparsi di cosa il Patriarca riferiva," N. 3668/35, 18 October 1935, f. 128.

${ }^{63}$ ASV, ANB, n. 194, "Pro-Memoria".

${ }^{64}$ AAES, IV Periodo, Turchia, Palestina, 131 P.O., fasc. 115 (1932-1936), "Centre International de Defense des Intérets Catholiques en Palestine. Pro Memoria," N. 2, enclosed with the letter, N. 415/34, from the Latin Patriarch of Jerusalem, Luigi Barlassina, I Febraury 1934, f. 92 .

${ }^{65}$ ASV, ANB, n. 194, "Riservata," N. 10813.

${ }^{66} \mathrm{ASV}, \mathrm{ANB}$, n. 194, "Pro-Memoria".

${ }^{67}$ Clarke, "Theorising the role of cultural," 148-150.

${ }^{68}$ ASV, ANB, n. 194, "Pro-Memoria". 
Palestinian office of the Centre would ensure a stream of approved information about local Catholics so that their condition could be known of beyond the territory and the region, entertaining a direct relationship with different international audiences (mainly French-speaking, but also Italian, German and Dutch), but always with the necessary prudence. ${ }^{69}$ In essence, these were the elements that would substantiate the non-state diffuse cultural diplomatic efforts promoted by the Latin Patriarch.

\section{The International Centre for the Protection of Catholic InTERESTS In PALEstine ANd Its ACtivities}

The Centre's daily activity was to publish articles and commentaries as well as organise thematic conferences, serving as a venue for exchange and discussion. ${ }^{70}$ These undertakings were performed according to a precise rationale. It is worth noting that such a logic also explains the Centre's shortcomings and the reasons why it had suddenly disappeared shortly after its foundation.

The International Centre functioned as a "content creator" without its own media but with a network of contacts to disseminate information and follow-up stories, developing knowledge and awareness and organise conferences. ${ }^{71}$ Initially, the Patriarch planned a monthly Bulletin and the establishment of distinct national branches, but these remained only a proposal. ${ }^{72}$ Although such a framework could have been an efficient solution to reduce costs and overcome the challenges experienced from shortly after its foundation, this rationale fragmented the Centre's activities, forcing it to bargain daily to publish its content. The result of conditions was that it is almost impossible to concretely measure the extent of its dissemination activity, but it appears episodic and unevenly distributed. On top of this, the archival documentation does not provide a systematic catalogue of the published articles, but only of the reports and texts drafted by the Jerusalem office which gave rise to them. ${ }^{73}$ In this regard, the archives offer evidence of three

\footnotetext{
${ }^{69}$ ALPJ, LB 9 Intérets de Catholiques en Palestine, 1930-1933/1935, "Pro-Memoria," October 1933, f. 25,1 .

${ }^{70}$ AAES, IV Periodo, Turchia, Palestina, 131 P.O., fasc. 115 (1932-1936), "Progetto Centro internazionale," N. 108/32, f. 58.

${ }^{71}$ AAES, IV Periodo, Turchia, Palestina, 131 P.O., fasc. 115 (1932-1936), N. 522/32, from the Latin Patriarch of Jerusalem, Luigi Barlassina, to the Nuncio to Belgium, Clemente Micara, Jerusalem, 5 October 1932, f. 97. AAES, IV Periodo, Turchia, Palestina, 131 P.O., fasc. 115 (1932-1936), "Progetto Centro internazionale per la Palestina," N. 108/32, f. 57r. See also: ASV, ANB, n. 194, "Riservata," N. 10813, from Secretary of the Sacred Congregation of Extraordinary Ecclesiastical Affairs, Giuseppe Pizzardo to the Nuncio to Belgium, Clemente Micara, Roma, 2 April 1932.

${ }^{72}$ ASV, ANB, n. 194, "Pro-Memoria".

${ }^{73} \mathrm{ASV}, \mathrm{ANB}$, n. 194. ALPJ, LB 9 Intérets de Catholiques en Palestine, 1930-1933/1935. AAES, IV Periodo, Turchia, Palestina, 131 P.O., fasc. 115 (1932-1936).
} 
macro-set of publications that should have been disseminated through articles in different languages. The titles are: "the Catholic institutions in Palestine" (1933), a long article, almost a report, about the legal rights and privileges of Catholicism before and after the Great War, with a note describing the main points to be discussed in dedicated conferences; "Catholicism, Zionism and a Legislative Council in Palestine" (1935); and the "the partition project of Palestine is harmful for Christianity" (1937).

The last two topics dominated the Jerusalem office's concerns. Between 1935 and 1937, Barlassina continuously urged the Centre to publicise the importance of granting representation to Catholics in the Legislative Council. The project of a Legislative Council appeared to Barlassina as the answer to all his worries. In his missives, Barlassina underlined that this sort of new Parliament would probably be based on the current demography in Palestine, without any respect for the traditional rights of its populace, in particular the Catholics. ${ }^{74}$ The number of Jews was increasing, while Christians were already declining, as the 1931 Census certified. ${ }^{75}$ In this framework, the British authorities intended to grant "all the Christians" only one single seat, against 6 for Muslims and 3-4 for Jews. This would have ratified the marginalisation of Christianity.

Such concerns grew following the publication of the result of the Royal Commission's mission in Palestine. The text not only advanced the idea of partition, but it proposed to grant the Zionists territories densely inhabited by Christians, and especially Catholics. In the mind of Barlassina this would have inevitably entailed the exclusion of Catholics. They would have become a minority divided between two distinct political fields; their rights expropriated. In one report in 1937, the Patriarch clearly framed the condition of Catholics as that of a minority within a minority, namely Christian Orthodox. ${ }^{76}$ The Patriarch had never before framed the condition of Catholicism as such, and this new approach to its status was not simply the acceptance of a "new" political grammar, but seemed coherent with the set of initiatives inspired by the Patriarch to gain recognition for and defend the rights of Catholicism. The International Centre should have reminded British authorities and public opinion that local Catholics could be considered a minority in Palestine, but that their rights and interests were those of world Catholicism. As seen before, these concerns were not new, but in the late 1930s the possibility that the Mandate would end without first fully recognising Catholic rights

\footnotetext{
${ }^{74}$ AAES, IV Periodo, Turchia, Palestina, 131 P.O., fasc. 115 (1932-1936), "Consiglio Legislativo," N. 1050/35, letter from the Latin Patriarch of Jerusalem, Luigi Bralassina, to Secretary of the Sacred Congregation of Extraordinary Ecclesiastical Affairs, Giuseppe Pizzardo, Jerusalem, 8 October 1935, ff. 120-121.

75 Pieraccini, La Diocesi Patriarcale, 565.

${ }^{76}$ ALPJ, LB 9 Intérets de Catholiques en Palestine, 1930-1933/1935, Conferenze ecclesiastiche sui privilegi e le riforme necessarie, "Risposte supplementari 1140/37 al Rapporto 1085/37," Jerusalem, 11 August 1937, 1.
} 
was viewed with alarm. ${ }^{77}$ In 1937 , such an event was not so remote. In fact, while Barlassina was writing these words, the Royal Commission had already put forward the result of its inspections, underlining the impossibility of proceeding with the current state of affairs and thus proposing the partition of Palestine. In this framework, Barlassina used the word "minority" to stress the British authorities' duty to fulfil their Mandate, protecting minorities in Palestine, and their material and spiritual rights. He also employed such a grammar to suggest that the Holy See highlight the failure of the Mandate to remain faithful to its duty to protect "minorities", coherently asking for its revision and the internationalisation of Palestine, or at least the part mostly inhabited by Christians and where the Holy Places stand.

In this framework, the archive documentation helps to assess the International Centre's activity. On the one hand, the reply from Rome to Barlassina clearly confirms that the words of the Patriarch were considered of extreme importance. Secretary of Congregation of Extraordinary Ecclesiastical Affairs, Pizzardo, asked to Barlassina to provide him with further information in order to be able to effectively negotiate with the British authorities. ${ }^{78}$ Looking at these requests one can appreciate precisely the poor results of a Centre called to disseminate information on Catholics in Palestine. Pizzardo did not simply ask Barlassina to provide more information regarding the demographic distribution of Catholics in Galilee, Judea and Samaria. He also asked him to prepare a precise and updated list of rights and interests of Catholics, exactly the topics that the International Centre should already have disseminated. At the same time, although the Centre seems to have published a series of articles, the quality of these appears to have been quite different from those drafted in 1933. The archive preserves a sample of the original draft, written in Spanish, which is less concerned with providing concrete information and developing knowledge on the issue at stake. Rather, it is focused on mobilising public opinion empathically. Knowing that shortly after this article the Centre ceased to function, such a difference reveals that in essence Barlassina's project had failed to materialise.

Similarly, when the Centre's dissemination strategy is discussed, it mostly provides insights into the shortcomings in coordination between Jerusalem and Brussels. There are two examples that illustrate this. First, in 1935, while the creation of a Legislative Council was being discussed in Palestine, Barlassina proposed a communication strategy to win the maximum coverage possible on the conditions of Catholics in the Mandate. He suggested avoiding the sole publication of the drafted articles in Jerusalem. Instead, the Centre should use them as the basis for promoting different articles in order

\footnotetext{
${ }^{77}$ Ibidem, 2.
}

${ }^{78}$ ALPJ, LB 9 Intérets de Catholiques en Palestine, 1930-1933/1935, Conferenze ecclesiastiche sui privilegi e le riforme necessarie, "N.3124/37," letter from Secretary of the Sacred Congregation of Extraordinary Ecclesiastical Affairs, Giuseppe Pizzardo, to the Latin Patriarch of Jerusalem, Luigi Bralassina, the Vatican, 7 August 1937. 
to multiply their effects. He thus invited the Centre to ask Nunciatures to France, Germany, Netherlands, Spain and the diocese of Westminster to publish the greatest number of articles. ${ }^{79}$ These seem to be the countries and languages of the Centre's outreach activity. Accordingly, such an approach can be considered appropriate given the mission of the Centre. Nevertheless, it immediately fostered misunderstanding and tensions between Jerusalem and Belgium. The Patriarch desired the integral publication of the articles dispatched to Belgium. The European headquarters replied to Barlassina that it would be difficult to fulfil such a request. The articles were too long, and it was unlikely that journals would accept to simply re-publish old articles. Therefore, Brussels suggested that it should prepare excerpts to make their publication easier. This annoyed Barlassina.

A couple of articles published by the Austrian Catholic journal the Reichspost in 1935-36 offers another illuminating example. Although the articles explicitly referred to the Centre and its Palestinian committee, it is not possible to say if these had been directly requested or inspired by Brussels and Jerusalem. Nevertheless, they were quite successful in triggering debate in the contemporary media in Palestine. In fact, the articles were commented on by the Palestine Post and Filastinn. At the same time, this episode also offers clues regarding the International Centre's shortcomings and limits. The archival documentation shows that after the Reichspost, the Palestine Post published an article raising the idea that Italy was trying to interfere in Palestine by exploiting requests put forward by Catholic institutions in the Mandate. Immediately, a correction was sent to the Palestine Post to react against this distortion of reality. The "(anonymous) authoritative Catholic source" that sent the new article explained that the only interests of Catholics in Palestine were in defending their rights. There was no intention of engaging in polemics with British authorities and any attempt to search for external aid and support from other countries was excluded. ${ }^{80}$ Beyond the content of the reply, such a correction is particularly interesting because it seems to contradict one of the founding principles of Barlassina's project. Although the Centre was meant always to work publicly, the correction sent to the Palestine Post was entrusted to an anonymous author (quite probably of the Latin Patriarchate or by someone in contact with it). In particular, it is indicative that the Patriarchate decided to adopt such methods instead of asking the Centre directly to publicly reiterate its vision and mission. This is revealing given the article's direct reference to the mission and code of conduct of the Centre. The International Centre's silence can be considered indicative of the internal difficulties that it was already experiencing during its first year of existence.

\footnotetext{
${ }^{79}$ AAES, IV Periodo, Turchia, Palestina, 131 P.O., fasc. 115 (1932-1936), "Riflessione su missiva di Barlassina e su proposta di strategia divulgativa," 20 November 1935.

${ }^{80}$ AAES, IV Periodo, Turchia, Palestina, 131 P.O., fasc. 115 (1932-1936), "Appunto," Rome, 29 January 1936, f. 146.
} 
In this setting, in 1937 Barlassina communicated to the Holy See his frustrations towards his long-awaited project. In his report, titled "How to defend Catholic Interest in Palestine" (1937), the Patriarch condemned the failure of the Centre in Brussels. Barlassina explicitly criticised the inaction of the Brussels office and its modus operandi. He could not accept the editing of his articles and their uneven dissemination. According to him, this chapter in the history of the project should be quickly closed with the aim of reviving it through the involvement of the International Young Catholics, who could have been asked to join the Centre. Nevertheless, the proposal remained unanswered, showing that the Holy See probably considered the project failed as well.

The balance of the International Centre's activities is, therefore, quite meagre. While remaining an interesting initiative, innovative in character, it failed to impose itself as an alternative path to articulate the interests of Catholicism in the Holy Land. The reasons that brought about its closure only after few years are probably contained in its own code of conduct and organisation. It essentially remained a top-down initiative, fully controlled by the Latin Patriarch. He thus excluded the participation of the local Catholic faithful at any level and tried to close all spaces of autonomy to anyone who was not part of the ecclesiastical hierarchy in Palestine. In this regard, the Reichspost case is indicative. According to Barlassina, this rationale should have shielded the Patriarchate. Nevertheless, it instead undermined the Centre's impact and narrowed its vision. The Centre and Barlassina exclusively committed to legal and institutional means, without giving a voice to local Catholics' views and needs. In essence, it exclusively concentrated on defending the "tradition" (namely Catholic rights assured by French Catholic protectorate at the time of the Ottoman Empire) rather than seeking on articulating a new vision of the Catholic presence fully involving local Arab Catholics. Furthermore, the complex and fragmented procedures combined with the lack of a precise strategy, isolated and jeopardised its activities. In this guise, the Centre remained only an experiment and a first attempt at cultural diplomacy and outreach. The spaces for exchange and outreach were limited in numbers and quality and the Centre seems to have remained a mere symbol. This probably contributed to its disappearance from memory once it suddenly ceased to function, probably as soon as 1935 and definitively in $1937 .{ }^{81}$

\section{Conclusion}

Beyond the historical significance of such an initiative, the archival documentation on the International Centre provides a useful perspective from which to deduce the Catholic hierarchy's understanding of the interests, issues and the challenges at stake, and their priorities for addressing them. It is a window

\footnotetext{
${ }^{81}$ Last document preserved in the archive of the Latin Patriarchate of Jerusalem dealing with the Centre refers to the Royal Commission 1936-1937.
} 
through which to examine how the Catholic Church, at different levels, felt about the situation in Mandate Palestine, the challenges to the present and future status of Catholics in this land and, more widely, the role of international public opinion in the politics and diplomacy of the time.

The establishment of the International Centre and its analysis from the perspective of cultural diplomacy and outreach offers a different angle from which to research a parallel front in the political struggle for state, self-determination and existence in Mandate Palestine, namely the battle for ideas over political identity and the destiny of the territory, its communities and people. It also sheds light on the process of internationalising the Palestinian question from the distinctive perspective of a specific religious rite (Latin Catholic) at the heart of a precise denomination (Catholicism) characterised by a diverse presence, made up of Arab-speaking and non-Arab faithful, and under the direction of an institution that was part of a complex local and transboundary ecclesiastical network (the Latin Patriarchate of Jerusalem). Finally, this microhistory provides a circumscribed field in which to reconsider the complex dynamic of defining Christian, and specifically Catholic and Latin, essence, life, characteristics and conditions. The International Centre was, therefore, a project that cut across multiple levels. It not only involved a broad network of personalities and institutions in Palestine and abroad, but also intertwined two different, and unequal, levels of exchange. On the one hand, it was designed to be a voice from Palestine, a window opened to the international community that from below would present the "real" and "true" experiences of the Catholics in this land. On the other, as a consequence of the extreme centralisation of this initiative and the absence of native Arab clergy involved, the International Centre was inevitably viewed as a top-down enterprise narrating from above a specific idea of the identity, needs and challenges of the Catholic community in the Holy Land.

Barlassina and the Latin Patriarchate showed a great sense of modernity in understanding the importance of reaching out to different audiences with the aim of finding a position in the developing Palestinian question. He invited the Latin community to avoid engaging in concrete politics, maintaining a certain neutrality between the main political fronts. But, at the same time, he directly promoted the Latin Patriarchate's voice, aspiring to develop a sort of soft power in the ongoing battle for ideas to defend Catholic interests. It is in this framework that these initiatives can be ascribed simultaneously to the fields of pastoral mission, communication, politics and diplomacy.

\section{BIBLIOGRAPHY}

\section{ARCHIVAL SOURCES}

Archive of the Latin Patriarchate in Jerusalem (ALPJ):

LB 9 Intérets de Catholiques en Palestine. Box: Documenti e lettere che riguardano il centro per salvaguardare gli interessi cattolici in Palestina (1930-1933/1935); 
Box: Documenti governativi sulle garanzie e diritti dei cattolici in Palestina; Documenti relativi all'affare 1935; Mandato.

GV-AG 1.7-1, Visite Canoniche Parrocchie, 1874-1957.

Lettere pastorali (Pastoral letters).

Archivi degli Affari Ecclesiastici Straordinari (ASCAE), Indice delle carte del Quarto

Periodo, Comprende il Pontificato di Pio XI (dal 1922 al 1939), Turchia:

P.O, fasc. 15 (1922-1939).

P.O, fasc. 64 (1925-1931).

-106 P.O, fasc. 101.

P.O, fasc. 103 (1929-1933).

P.O., fasc. 115 (1932-1936).

Archivio Sacra Congregazione per le Chiese Orientali (ASCCO):

Latini, Palestina e Transgiordania: Patriarcato di Gerusalemme, 559/41 (603/28).

Latini, Palestina e Transgiordania: Patriarcato di Gerusalemme, 335/37.

Latini, Palestina, Latini Palestina Aff. Generali e Del. Apostolica, 417/Prop.

Archivio Sacra Congregazione Propaganda Fide (ASCPF), Acta, Terra Santa, Missioni di Palestina, vol. 291, pon. 14/VI/1920.

Archivio Segreto Vaticano (ASV), Archivio della Nunziatura in Belgio (ANB), n. 194.

\section{SECONDARY SOURCES}

Clarke, David. "Theorising the Role of Cultural Products in Cultural Diplomacy from a Cultural Studies Perspective." International Journal of Cultural Policy 22, no. 2 (2016): 147-163.

Dreuzy, Agnes de. The Vatican and the Emergence of the Modern Middle East. Washington, DC: CUA Press, 2016.

Haiduc-Dale, Noah. Arab Christians in British Mandate Palestine: Communalism and Nationalism, 1917-1948: Communalism and Nationalism, 1917-1948. Edinburgh: Edinburgh University Press, 2013.

Hajjar, Joseph N. Un lutteur infatigable: le patriarche Maximos III Mazloum. Harissa: Imprimerie Saint Paul, 1957.

Mazza, Roberto. Jerusalem: From the Ottomans to the British. London: I.B. Tauris, 2009.

Pieraccini, Paolo. "Il Patriarcato Latino di Gerusalemme (1918-1940): Ritratto di un patriarca scomodo: Mons. Luigi Barlassina." Il Politico, nos. 2-4 (1998): 207-256, 591-639.

Pieraccini, Paolo. "La Diocesi Patriarcale Latina di Gerusalemme, La Santa Sede e le Grandi Potenze dal crollo dell'Impero ottomano alla Seconda guerra mondiale (1917-1939).” PhD diss., Università degli Studi di Firenze Facoltà di Scienze Politiche "Cesare Alfieri", 2008-2009.

Robson, Laura. Colonialism and Christianity in Mandate Palestine. Austin: University of Texas Press, 2011.

Sanchez Summerer, Karène. "Linguistic Diversity and Ideologies Among the Catholic Minority in Mandate Palestine. Fear of Confusion or a Powerful Tool?" British Journal of Middle Eastern Studies 43, no. 2 (2016): 191-205.

Zanini, Paolo. "Il Centro internazionale per la protezione degli interessi cattolici in Palestina." Studi storici 54, no. 2 (2013): 393-418. 
Zanini, Paolo. "The Holy See, Italian Catholics and Palestine Under the British Mandate: Two Turning Points." Journal of Ecclesiastical History 67, no. 4 (2016): 799-818.

Zanini, Paolo. "The Establishment of the Apostolic Delegation to Palestine, Cyprus, and Transjordan (1929): Cause or Effect of Changes in Vatican Middle East Policy?” Church History 87, no. 3 (2018): 797-822.

Open Access This chapter is licensed under the terms of the Creative Commons Attribution 4.0 International License (http://creativecommons.org/licenses/ by $/ 4.0 /$ ), which permits use, sharing, adaptation, distribution and reproduction in any medium or format, as long as you give appropriate credit to the original author(s) and the source, provide a link to the Creative Commons license and indicate if changes were made.

The images or other third party material in this chapter are included in the chapter's Creative Commons license, unless indicated otherwise in a credit line to the material. If material is not included in the chapter's Creative Commons license and your intended use is not permitted by statutory regulation or exceeds the permitted use, you will need to obtain permission directly from the copyright holder.

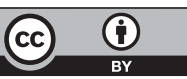

